\title{
The Implementation of Audio Visual Media in Problem Based Learning Model to Improve the Problem Solving Skills
}

\author{
Winda Arwin Setyani ${ }^{1, *}$ Jumadi $^{2}$, Amri Suko Darmawan ${ }^{1}$ \\ ${ }^{1}$ Master of Physics Education, Faculty of Mathematics and Natural Sciences, Universitas Negeri Yogyakarta, \\ Indonesia \\ ${ }^{2}$ Department of Physics Education, Faculty of Mathematics and Natural Sciences, Universitas Negeri \\ Yogyakarta, Indonesia \\ *Corresponding author. Email: windaarwin.2019@student.uny.ac.id
}

\begin{abstract}
This study aims to determine the increase in problem solving skills of students in MAN 3 Yogyakarta through audio visual media in Problem Based Learning (PBL) model. The method used in this research is a quasiexperimental design with an experimental design, namely one group pre-test-post-test design. The sampling use purposive sampling technique with participants were 31 student from year 11 class in MAN 3 Yogyakarta. The result is showed that there was an increase in the problem solving skill of students of MAN 3 Yogyakarta which was indicated by the results of the Wilcoxon test, it was known that the significance was $0.000<0.05$. It can be concluded that problem solving skills improve by applying audio visual media in a problem-based learning model in MAN 3 Yogyakarta.
\end{abstract}

Keywords: Learning media, Audio visual, E-learning, Problem based learning, Problem solving skills

\section{INTRODUCTION}

Science and technology is growing rapidly. As citizens, they must be prepared to face these challenges. Several steps have been taken by the Government of Indonesia, including improving the quality of human resources (HR), namely through education. Science and technology is here to facilitate teachers and students in the learning process, one of which is through e-learning [1] [2]. During the COVID-19 pandemic, students were required to learn from home, so they could not meet face to face with the teacher as usual in school [3]. Because of this policy, the use of e-learning in learning is very important. E-learning can make it easier for teachers to deliver material that students can access at any time. The learning process can be done anytime and anywhere because teachers and students can learn without meeting in person. Some of the available elearning platforms are Moodle, Google Classroom, Edmodo which can contain materials, assignments and other information. The success of online learning in Indonesia during this Pandemic COVID-19 was determined by the readiness of the technology, both from the teacher and student side. The technology is in line with the curriculum, support and collaboration of all stakeholders [4]. Although using e-learning, if the concept is virtual class, it has not been effectively used for learning physics. E-learning that is used will be more effective using learning videos or physics practicum videos [5]. The use of e-learning requires readiness including readiness to prepare more innovative teaching materials, so that it will increase students' interest in learning [6]. Teaching materials in digital form such as videos are easier to understand and more efficient in use. However, there are still many obstacles that are felt, especially by teachers in preparing these teaching materials because it requires a little longer time [7].

The importance of science and technology in education, namely science and technology as provisions for the 21 st century. Audio visual media has an important role in this modern education, because it has many advantages including the advantages of intuition, clarity, representation, and abundant information [8]. The use of audio visual media technology in education can generate 
motivation and stimulation of perceptual skills which will lead to increased learning outcomes of students [9].

The development of the 21 st century requires students to have several skills, one of which is problem solving skills [10]. Problem solving skills is the skill of students to use their knowledge in selecting or deductively predicting various possible consequences of a phenomenon [11]. The skill to solve problems itself is a very important part of learning because in the learning process and its solution, students are allowed to gain experience using the knowledge they already have [12].

There are several learning models that can improve problem solving skills. One of them is a learning model that focuses on solving everyday problems, namely the Problem Based Learning (PBL) model. PBL is a learning model that encourages students to learn and work together in groups to find solutions to problems in the real world, PBL allows students to work collaboratively and build their knowledge through social interaction [13][14][15]. Students who have gone through the learning process using the problem-based learning model will take the final exam or test more relaxed and not tense because they are used to facing problems during learning and we know that the student has passed the test, based on their final grade [16], [17].

With these problems, teacher innovation is needed in delivering material during the learning process, for example by using different learning media, namely by using audio visual media. This study aims to determine the increase in students' problem solving skilss using audio visual media in the PBL model.

\section{RESEARCH METHOD}

\subsection{The Type of Research}

This study used the Quasi Experiment method with the research design using the one group pre-testpost-test design [18]. The design form is as in table 1.

Table 1. Research design one group pre-test-post-test design

\begin{tabular}{|c|c|c|c|}
\hline Group & $\begin{array}{c}\text { Initial } \\
\text { Test }\end{array}$ & Treatment & $\begin{array}{c}\text { Final } \\
\text { test }\end{array}$ \\
\hline Experiment & $\mathrm{O} 1$ & $\mathrm{X}$ & $\mathrm{O} 2$ \\
\hline
\end{tabular}

$\mathrm{O}_{1}$ is the initial test (pre-test) carried out before being given treatment. $\mathrm{X}$ is a treatment given to students by applying audio visual media with PBL model. $\mathrm{O}_{2}$ is the final test (post-test) carried out after being given treatment.

\subsection{The Place and Time Research}

The place of research at MAN 3 Yogyakarta that's located in Magelang St km. 04, Kutu Dukuh, Sinduadi, Mlati, Sleman Regency, Special Region of Yogyakarta. The research period is April to May 2020.

\subsection{The Research Subject}

The research subjects were students of class XI MIPA 1, MAN 3 Yogyakarta. The research subjects were determined using purposive sampling technique [19]. The number of research subjects consisted of 31 students of class XI MIPA 1.

\subsection{The Research Variable}

In this study, the independent variable was the audio visual media with PBL model, while the dependent variable was the problem solving skills.

\subsection{The Instruments}

Before the research, the video was uploaded to the e-learning madrasah of MAN 3 Yogyakarta. Videos contain problems that students solve. There were 3 problems that were solved by the students, namely videos 1,2 and 3 . Video 1 is given to students after a pretest is done. The problem in video 1 is how students can observe a solar eclipse using a telescope (figure 1).

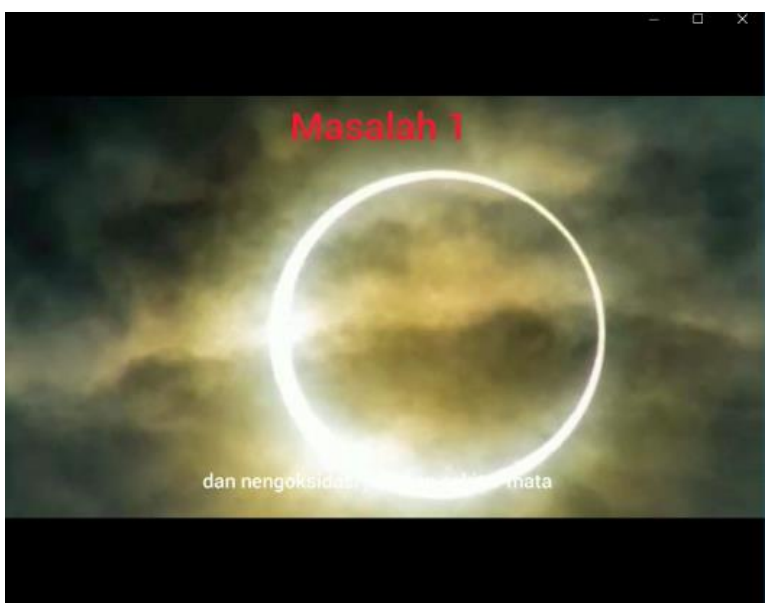

Figure 1 Video of learning 1

Students can discuss these problems with the help of the teacher. When problem one has been solved, 
students are given video 2 in which students can find out how the telescope works (figure 2).

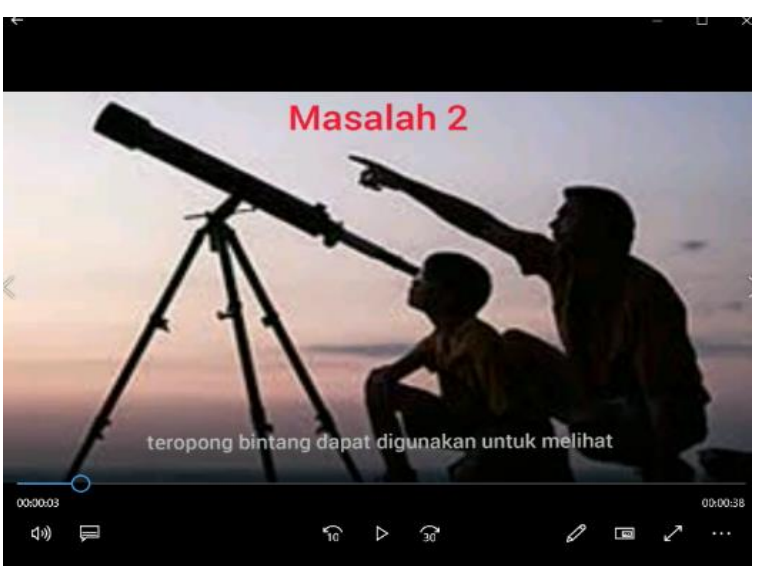

Figure 2 Video of learning 2

Students can solve these problems with the help of the teacher. After that, students were given video 3 which contains the problem of how someone can see objects that are very far away on earth and how they work (figure 3). The issues included in the video are designed in such a way that the content of the video is carefully constructed as a problem [20].

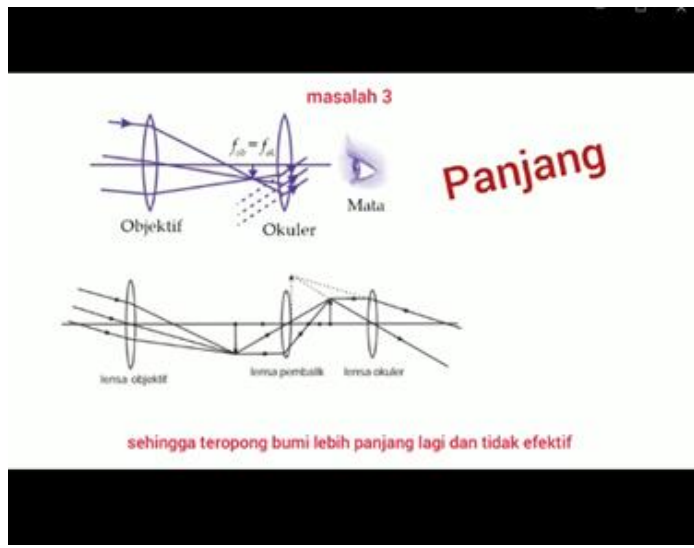

Figure 3 Video of learning 3

PBL problems are structured based on three important aspects of PBL problems, namely unstructured, contextual and related to everyday real life situations [21]. Student worksheets are provided for problem solving. Problem solving from the information provided in the instructional videos. Even though using e-learning, students are still divided into several groups, with each group presenting the results of the problem from the video given.

The fourth video that has been developed by the teacher contains a summary of the optical material explanation for reflection, evaluation and reinforcement of the material for students (figure 4). So that the teacher does not need to explain again, because it is represented by video 4 . Students can listen to and see the content of the video regarding the material discussed at the meeting. Videos are given to provide constructive feedback followed by closing the lesson [22]. The video has been equipped with voice and text that can help students easily understand the content of the video.

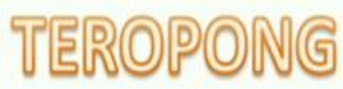

\section{MATERI FISIKA SMA KELAS XI}

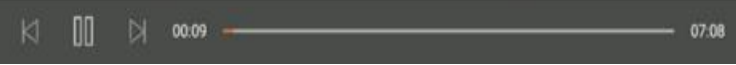

Figure 4 Video of learning 4

\subsection{Data Collections Instruments And Analysis}

\subsubsection{Data Collections}

The pre-test and post-test were given to solve students' problem skills before treatment using PBL videos and after treatment using PBL videos. The post-test was given after learning PBL through the video given. The test questions are uploaded to the elearning madrasah of MAN 3 Yogyakarta, so that students work online with a time limit of 60 minutes. The questions consist of items that test students' problem solving skills.

\subsubsection{Analysis}

The data processing technique in this research is quantitative. Quantitative data were analyzed using statistical calculations with the help of SPSS. Quantitative data were generated from the pre-test and post-test scores. The test results were tested for normality and average differences using the Wilcoxon test.

\section{RESULT AND DISCUSSION}

\subsection{Problem Solving Skills}

The results of the pre-test-post-test were processed using SPSS. First, the pre-test and post-test data were analyzed using the normality test, in order 
to know whether the data was normal or not. Because the data amounted to 31, then using the Shapiro Wilk normality test [23]. The results of the normality test are as follows as table 2 .

Table 2. Test of normality for the pre-test and posttest scores

\begin{tabular}{|c|c|c|c|}
\hline Test & \multicolumn{3}{|c|}{ Shapiro-Wilk } \\
\hline Pre-Test & 0.908 & 31 & 0.011 \\
\hline Post-Test & 0.938 & 31 & 0.075 \\
\hline
\end{tabular}

In the pre-test data, the sig. $0.011<0.05$, the data is not normal. Meanwhile, the post-test data sig. $0.075>0.05$, the data is normal. Because only one of the data was normally distributed, a non-parametric statistical test was performed using the Wilcoxon test to check between the pre-test and post-test whether there was a statistically significant difference in the mean scores.

Tabel 3. The test of Wilcoxon

\begin{tabular}{|c|c|}
\hline Information & Post-Test - Pre-Test \\
\hline $\mathrm{Z}$ & $-4.399^{\mathrm{b}}$ \\
\hline Asymp. Sig. (2-tailed) & 0.000 \\
\hline
\end{tabular}

Based on the Test Statistics output above, it is known that Asymp.Sig. (2-tailed) is worth 0.000 (table 3). Because the value of 0.000 is less than 0.05 , it can be concluded that there is an increase in skills in solving physics problems using the audio visual media.

Table 4. Mean scores for the pre-test and post-test scores.

\begin{tabular}{|c|c|}
\hline Data & Average Score \\
\hline Pre-test & 44.2 \\
\hline Post-test & 73.2 \\
\hline
\end{tabular}

Table 4 shows that there is a significant difference between the mean before the use of audio visual media and after the use of audio visual media. The average Pre-test score is 44,2 meanwhile the average Post-test score is 73,2.

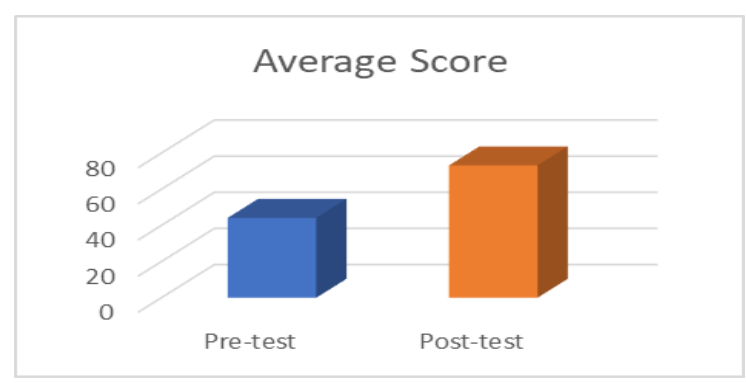

Figure 5 Average Score of pre-test and post-test
Figure 5 shows that the problem-solving of physics increases after the application of audio visual media. The average score increased from pre-test 44,2 to post-test 73,2 . The factors that cause the effect of giving treatment to the problematic skills improvement are the learning media and learning models used. The audio visual media used by students is easier to understand and understand the material being taught when learning using e-learning. The use of audio visual media is able to improve student perceptions of learning, understanding or understanding, the delivery of learning from teachers to students, improving memory and being able to provide improvement or knowledge of the results achieved. In addition, attractive media can make students more interested in participating in learning activities, where high interest in learning greatly affects student learning outcomes. During the learning process, students in the experimental class tend to enjoy learning that is combined with learning media. Students find it easier to understand known concepts with animation aids that are prepared as teaching aids [24].

Learning using audio visual media seen through e-learning owned by MAN 3 Yogyakarta is proven to be effective in improving student problem skill test results. This is in line with previous research that online PBL is as effective as PBL conducted in person in class [25]. Although there are still obstacles, there are the limited ability of students' discussion technology during PBL learning.

\section{CONCLUSION}

Learning using the audio visual media in PBL model is better at improving students' problem solving skills. These results were obtained from the pretest-posttest data analysis.There are supporting factors in improving students' problem solving skills. Among them are students discussing well, learning activities are fun, students are more aware of watching videos, there are worksheets that can be used as a tool to make it easier for students to understand learning concepts, students can consider different situations, some students enjoy challenges and are optimistic about learning.

Some limitation of this study are that learning physics through e-learning not yet controlled by arranging sessions during learning. Controlling learning can be through discussion groups. Teachers also need to be more interactive so that students have a high curiosity so that the results of problem solving skills increase significantly. 


\section{REFERENCES}

[1] M.Y.R.T. Kawuri, A. Jufriansyah, D.D. Setiamukti, D. Sulisworo, Implementation ELearning Based Moodle on Physics Learning in Senior High School, Indonesian Journal of Science and Education 3(2) (2019) 93-102. DOI: https://doi.org/10.31002/ijose.v3i2.1178

[2] D. Muliyati, H. Marizka, F. Bakri, E-Learning Using Wordpress on Physics Materials with The 5E Learning Cycle Strategy, Jurnal Penelitian \& Pengembangan Pendidikan Fisika 5(2) (2019) 101-112. DOI: https://doi.org/10.21009/1.05205

[3] D. Sikirit, Learning from Home during The COVID-19 Pandemic, Unicef, Jun. 2020. Accessed on: Jul. 23, 2020. [Online]. Available: https://www.unicef.org/indonesia/coronavirus/st ories/learning-home-during-covid-19-pandemic

[4] R.R. Aliyyah, R. Rachmadtullah, A. Samsudin, E. Syaodih, M. Nurtanto, A.R.S. Tambunan, The Perceptions of Primary School Teachers of Online Learning during The COVID-19 Pandemic Period: A Case Study in Indonesia, Journal of Ethnic and Cultural Studies 7(2) (2020) 90-109. DOI: https://doi.org/10.29333/ejecs/388

[5] A. Permata, Y.B. Bhakti, Keefektifan Virtual Class dengan Google Classroom dalam Pembelajaran Fisika Dimasa Pandemi Covid-19, Jurnal Inovasi Pendidikan Fisika Dan Riset Ilmiah 4(1) (2020) 27-33. DOI: https://doi.org/10.30599/jipfri.v4i1.669

[6] B. Setiaji, P.A.C. Dinata, Analisis Kesiapan Mahasiswa Jurusan Pendidikan Fisika Menggunakan E-Learning dalam Situasi Pandemi COVID-19, Jurnal Inovasi Pendidikan IPA 6(1) (2020) 59-70. DOI: $\underline{\text { https://doi.org/10.21831/jipi.v6i1.31562 }}$

[7] I. Yusuf, S.W. Widyaningsih,. R.B. Sebayang, Implementation of E-learning Based-STEM on Quantum Physics Subject to Student HOTS Ability, Journal of Turkish Science Education 15 (2018) 67-75. DOI: https://doi.org/10.12973/tused.10258a

[8] X. Xu, Z. Liu, The research of audio-visual teaching in college physics teaching practice, in: Y. Wang (Ed.), Education and Educational Technology, AISC 108, Springer, Berlin, Heidelberg, 2012, pp. 237-242. DOI: https://doi.org/10.1007/978-3-642-24775-0
[9] C. Nicolaou, M. Matsiola, G. Kalliris, Technology-Enhanced Learning and Teaching Methodologies through Audiovisual Media, Education Sciences 9(3) (2019) 196-208. DOI: https://doi.org/10.3390/educsci9030196

[10] P. Häkkinen, S. Järvelä, K. Mäkitalo-Siegl, A. Ahonen, P. Näykki, T. Valtonen, Preparing Teacher-Students for Twenty-First-Century Learning Practices (PREP 21): A Framework for Enhancing Collaborative Problem-Solving and Strategic Learning Skills, Teachers and Teaching 23(1) (2017) 25-41. DOI: https://doi.org/10.1080/13540602.2016.1203772

[11] F. Helmi, J. Rokhmat. Pengaruh Pendekatan Berpikir Kausalitik Ber-Scaffolding Tipe 2B Termodifikasi Berbantuan LKS Terhadap Kemampuan Pemecahan Masalah Fluida Dinamis Siswa, Jurnal Pendidikan Fisika dan Teknologi 3(1) (2017) 68-75. DOI: https://doi.org/10.29303/jpft.v3i1.332

[12] B. Yoannita, E. Budi, C.E. Rustana, Pengaruh self efficacy terhadap hasil belajar fisika melalui penggunaan model problem based learning, in: Prosiding Seminar Nasional Fisika (E-Journal), vol. 5, Universitas Negeri Jakarta, Jakarta, 2016, pp. 9-14. DOI: https://doi.org/10.21009/0305010302

[13] R. Polanco, P. Calderón, F. Delgado, Effects of A Problem - Based Learning Program on Engineering Students' Academic Achievements in A Mexican University, Innovations in Education and Teaching International 41(2) (2004) 145-55. DOI: https://doi.org/10.1080/1470329042000208675

[14] K. Goodnough, Enhancing Pedagogical Content Knowledge through Self-Study: An Exploration of Problem-Based Learning, Teaching in Higher Education 11(3) (2006) 301-18. DOI: https://doi.org/10.1080/13562510600680715

[15] S. Sungur, C. Tekkaya, Ö. Geban, Improving Achievement through Problem-Based Learning, Journal of Biological Education 40(4) (2006) 155-60.

DOI: https://doi.org/10.1080/00219266.2006.9656037

[16] A.G. Haji, S. Safriana, R. Safitri, The Use of Problem Based Learning to Increase Students Learning Independent and to Investigate Students' Concept Understanding on Rotational Dynamic at Student of SMA Negeri 4 Banda 
Aceh, Jurnal Pendidikan IPA Indonesia 4(1) (2015) 67-72.

DOI: https://doi.org/10.15294/jpii.v4i1.3503

[17] R. Noviatika, G. Gunawan, J. Rokhmat, Pengaruh Model Pembelajaran Berbasis Masalah Berbantuan Mobile Pocket Book Fisika Terhadap Kemampuan Pemecahan Masalah Peserta Didik, Jurnal Pendidikan Fisika dan Teknologi 5(2) (2019) 240-246. DOI: https://doi.org/10.29303/jpft.v5i2.1163

[18] J.W. Creswell, Research Design: Pendekatan Kualitatif, Kuantitatif, dan Mixed, Pustaka Pelajar, 2010.

[19] I. Etikan, S.A. Musa, R.S. Alkassim, Comparison of Convenience Sampling and Purposive Sampling, American Journal of Theoretical and Applied Statistics 5(1) (2016) 14.

DOI: https://doi.org/10.11648/j.ajtas.20160501.11

[20] H.C. Li, Implementing Problem-Based Learning in A Taiwanese Elementary Classroom: A Case Study of Challenges and Strategies, Research in Mathematics Education 14(1) (2012) 89-90,. DOI:

https://doi.org/10.1080/14794802.2012.657441

[21] J.R. Savery, Essential Readings in ProblemBased Learning: Exploring and Extending The Legacy of Howard S. Barrows, Interdisciplinary Journal of Problem Based Learnig 9(2) (2015) 5-15. https://doi.org/10.7771/1541-5015.1002

[22] C. Chin, Classroom Interaction in Science: Teacher Questioning and Feedback to Students' Responses, International Journal of Science Education 28(11) (2006) 1315-1346. DOI: https://doi.org/10.1080/09500690600621100

[23] J.F. Pallant, SPSS Survival Manual: A Step-byStep Guide to Data Analysis with SPSS, McGraw Hill, 2007.

[24] L.M.E. Prayudi, H. Sahidu, G. Gunawan, Pengaruh Penggunaan Media Audiovisual Dengan Pendekatan Metakognitif Berbasis Masalah Terhadap Hasil Belajar Fisika Siswa Kelas XI IPA Di SMAN 1 Gerung Tahun Pelajaran 2016/2017, Jurnal Pendidikan Fisika dan Teknologi 3(1) (2017) 55-60. DOI: https://doi.org/10.29303/jpft.v3i1.324

[25] R. Chen, Learner Perspectives of Online Problem-Based Learning and Applications from Cognitive Load Theory, Psychology Learning \&
Teaching 15(2) (2016) 195-203. DOI: https://doi.org/10.1177/1475725716645961 